\title{
Coffee Marketing Mechanism: Social Relations Between Farmers, Collectors, Certification Cooperatives, and Exporters in Aceh, Indonesia
}

\author{
Andriadi $^{1}$, Rizabuana Ismail ${ }^{1 *}$, Fikarwin ${ }^{2)}$, Badaruddin $^{1)}$, Ria Manurung ${ }^{1)}$, and Henry Sitorus ${ }^{1)}$ \\ ${ }^{1)}$ Sociology Master Study Program, Universitas Sumatera Utara, Jln. Dr. A Sofian No.1, Padang Bulan, \\ Medan, Sumatera Utara, Indonesia \\ ${ }^{2)}$ Department of Anthropology, Universitas Sumatera Utara, Jln. Dr. A Sofian No.1, Padang Bulan, \\ Medan, Sumatera Utara, Indonesia \\ ${ }^{*}$ Corresponding author: rizabuana@usu.ac.id \\ Received: 26 June 2019 / Accepted: 29 July 2019
}

\begin{abstract}
Several factors can influence the process of pricing mechanisms, namely competition between market participants, regulation, product quality, and consumer preferences. This is a challenge for Gayo Arabica coffee farmers, where coffee is the main commodity in Central Aceh Regency. This paper aimed to determine the social relations that occur between social actors (farmers, collectors, certification cooperatives and exporters) in the coffee marketing mechanism. This paper used a qualitative research method with a survey approach by conducting interviews with farmers, collectors, certification cooperatives and exporters. The results showed that the marketing of Gayo Arabica coffee involved several layers of actors. The coffee product marketing system can be done through two facilities, namely through export sales and domestic sales. There are differences in the income of coffee farmers in marketing coffee abroad or in the country where farmers benefit more from selling coffee products for exports. Relationship among actors are interdependent and bound. Farmers need collectors as tool providers and coffee price informans. Farmers follow cooperative certificates to get fair and more profitable prices.
\end{abstract}

Keywords: Marketing mechanism, social relations, coffee farmers, collector traders, cooperative certification

\section{INTRODUCTION}

Coffee has been cultivated across Indonesia's major islands from the west part to the east. Currently there are about 1.2 million hectares of coffee plantation consisting of 899,627 ha of Robusta cofee and 330,373 ha of Arabica coffee. Data in 2016 showed that Indonesia's coffee total production reached 639.305 tons consisting of 466,492 tons of Robusta coffee and
172,919 tons of Arabica coffee (Ditjenbun, 2016). The commodity contributes US $\$ 824$ million to the state income. The bountiful production are supported by the climate and altitude of the farm which is very suitable for the coffee crop agro-climate. The high production of Indonesian coffee encourage the coffee industry to continue to grow and spread in all provinces in Indonesia ranging from Aceh to Papua with different qualities and quantities (Martauli, 2018). The Sumatera 
Island contributes $68 \%$ of the total productions with sources located in various places such as South Sumatra (17.2\%), Lampung (17.2\%), Aceh (7.4\%), Bengkulu (8.8\%). The remaining is located in Sulawesi (6.5\%), Java (17\%), Nusa Tenggara (6.7\%), Kalimantan (1.0\%), and Maluku and Papua (0.4\%) (Ditjenbun, 2016). This data places Indonesia in the fourth place in the world as the main coffee exporter after Brazil, Vietnam, and Colombia (Sari \& Tety, 2017). Coffee plays an important role in the livelihood of smallholder farmers. The International Coffee Organization noted that coffee supports farmers and provide them with substantial employment opportunities. Coffee cultivation requires an extension of labor, especially in the production process and in the harvesting process, which makes coffee as an important aspect of development in rural areas (Sarirahayu \& Aprianingsih, 2018).

In the Central Aceh Regency coffee has become the main commodity produced by smallholder plantations as the main source of export activities and at the same time supporting the regional economic structure. The local residents have also relied on their lives to become coffee farmers. The marketing of Gayo Arabica coffee in international trade (New York market) is based on the product certification (Nurlina \& Putra, 2016). The international product certification of Gayo Arabica coffee includes organic and fairtrade certificate. In today's economy, most producers do not sell their products directly to the final consumers, thus the consumers will not directly buy their coffee/product directly from producers. Therefore, a marketing channel is needed to deliver the product from producers to consumers by involving marketing layers.

Several layers of marketing involved started from collecting traders, certification cooperatives, entrepreneurs and exporters. As in a study conducted in Dampit District, it was shown that there were several actors involved in the coffee contestation process such as big traders, coffee shops, small traders and exporters (Purnomo, 2018). This is because, that at each layer of marketing has limitations and attachments to the marketing layer above and below it. These limitations are related to the need for income as the results of coffee production among the farmers, capital ownership (money) for marketing participant in purchasing the coffee and transparency of the coffee price. While the attachment on the marketing layers is regarding the social capital which created some sort of dynamic social relations in the marketing of coffee.

\section{MATERIALS AND METHODS}

To analyze the marketing mechanism and social relations that occur between actors, this study used qualitative methods with a case study approach. The purpose of this paper was to find out the Gayo coffee marketing mechanism through the layers of actors involved in it. The reason the author chose Central Aceh Regency was the background of this article because in general, the Gayo Arabica coffee plantation is a community plantation (privately owned). In addition, there are coffee fruit processing and the existence of trade administration institutions such as collecting agents, coffee entrepreneurs, cooperatives (with certification and without certification) and exporters in the process of trading Gayo Arabica coffee. This paper analyzed about social relations that occur between actors, namely farmers, traders, and collectors. The respondents involved in this paper can summarize the following: 
Table 1. Description of respondents identity

\begin{tabular}{|c|c|c|}
\hline Respondent name & Age (year) & Job \\
\hline IM & 38 & $\begin{array}{l}\text { Employee in Dinas Perdagangan, Cooperative and UKM (community activity unit) Aceh } \\
\text { Tengah District }\end{array}$ \\
\hline $\mathrm{S}$ & 48 & Quality Control (QC) of X Cooperative - Takengon. \\
\hline WRB & 45 & The author of a book about Gayo Arabica coffee and coffee traders in Takengon. \\
\hline $\mathrm{RP}$ & 50 & Quality Control and Head of Warehouse in Y Cooperative Tanah Gayo \\
\hline IT & 35 & $\begin{array}{l}\text { Employee in the Administrative Section of the Y Cooperative in Baburayan Regency } \\
\text { Central Aceh Cooperative. }\end{array}$ \\
\hline A & 35 & $\begin{array}{l}\text { Quality Control at the Y Cooperative in Tanoh Gayo and a Gayo Arabica Coffee Cupper } \\
\text { in Central Aceh District. }\end{array}$ \\
\hline MA & 72 & $\begin{array}{l}\text { Head Organization of Masyarakat Perlindungan Kopi Gayo (MPKG) ex- Chairman of } \\
\text { Forum Kopi Aceh in } 2005 \text {. An activist who initiated The Geographical Indication (IG) } \\
\text { and Gayo Arabica coffee varieties G1 and G2 }\end{array}$ \\
\hline M & 40 & $\begin{array}{l}\text { Manager in CI Company in Aceh Tengah District and a coffee Q Grader Indonesia, especially } \\
\text { in Aceh Tengah District }\end{array}$ \\
\hline $\mathrm{T}$ & 45 & Manager in Y Cooperative in Takengon and a Gayo Arabica coffee cupper \\
\hline K & 50 & $\begin{array}{l}\text { Employee in Local government in Aceh Tengah District and owner of an organic pilot } \\
\text { garden. A coffee activist who initiated the Geographical Indications (IG) and Gayo Arabica } \\
\text { coffee varieties G1 and G2. }\end{array}$ \\
\hline AR & 40 & Quality Control in Z Cooperative, Aceh Tengah District and owner of Home Coffee Industry \\
\hline $\mathrm{AB}$ & 45 & The head of X Cooperative \\
\hline $\mathrm{T}$ & 60 & Coffee Farmer Arabica Gayo. \\
\hline S & 57 & Coffee Farmer Arabica Gayo. \\
\hline $\mathrm{Z}$ & 55 & Coffee Farmer Arabica Gayo. \\
\hline
\end{tabular}

Survey activities carried out by interviews and observations of selected respondents, where the respondents were chosen because they had experience working in this field and were involved in the process of buying and selling coffee in the Central Aceh District. This helps the data collection and information about the processes experienced by each actor in order to market the results of this coffee plantation both in national and international scope. Then the author also tries to find information about social relations between actors in the coffee marketing process, so that income can be known by coffee farmers.

\section{RESULTS AND DISCUSSION}

\section{The market mechanism of Gayo Arabica coffee}

The problem often faced by Gayo Arabica coffee farmer is their inability to negotiate the price of coffee. The farmers are always ended up to be the recipients of prices from buyers. The coffee trading system that has a fixed pattern concurrent with the marketing network structure often harms the farmers as they become the victim of the market. The lack of access which farmers have to the production process of the coffee, their inadequate knowledge about the coffee trade, has made the farmers increasingly difficult to accept various provisions and requirements demanded by the market participants.

In this paper it is stated that the main factor in determining the selling price of Gayo Arabica coffee from farmers to the Collectors is the quality of coffee cherry (the coffee fruit) which assesed by measuring the percentage of water content in the (dry) coffee beans. The purchasing price of the coffee made by the Collectors is based on the local market price which is a formulation of the price of the New York Market. The coffee cherry picked from the farmers' farms tends to vary in the types of the fruit maturity. The more uniform the ripeness is, 
Table 2. Purchase Arabica coffee at the farm level (coffee market price of IDR 64,000)

\begin{tabular}{|c|c|c|}
\hline Coffee type & Coffee price calculation & Purchase price \\
\hline $\begin{array}{l}\text { Cherry } \\
\text { Bean (Water content } \geq 40 \%\end{array}$ & $\begin{array}{l}\text { IDR64,000 × } 0.13 \times 12 \mathrm{~kg} \text { ) IDR99,840,- } \\
\quad(\text { IDR99,840 } 0.3 \text { ) IDR29,952,-- }\end{array}$ & $\begin{array}{c}\text { (IDR90,000 - IDR100,000) } \\
(\text { IDR28,000 - IDR30,000) }\end{array}$ \\
\hline $\begin{array}{l}\text { Information: } \\
-1 \text { kaleng } \\
-1 \mathrm{~kg} \text { of fresh cherry } \\
-1 \mathrm{~kg} \text { of dry coffee cherry } \\
-1 \mathrm{~kg} \text { of dry coffee cherry }\end{array}$ & $\begin{array}{l}=12 \mathrm{~kg} \text { (cherry). } \\
=0.13 \mathrm{~kg} \text { of green beans (water content } 11-12 \%) . \\
=0.3 \mathrm{~kg} \text { of green beans (water content } 11-12 \%) . \\
=0.5 \mathrm{~kg} \text { of unselected green beans (water content } 15 \% \text { ). }\end{array}$ & \\
\hline
\end{tabular}

the higher the price will be. Whereas for the coffee beans (dry), the processing of coffee is still through a traditional system. The drying process for the coffee beans is done by utilizing the sun. While for the measuring of the coffee beans size is done by assesing the physical shape and biting the coffee beans.

To measure the percentage of water content of the coffee beans the process is generallly done by looking at the physical shape of the coffee beans. However, the coffee farmers only process a certain amount of coffee beans, while the rest is usually done by the Collectors especially during the coffee harvest season. In terms of experience, the Collectors have better understanding on the percentage of water content of the grain and labu coffee beans compared to the farmers. Such condition is exploited by the Collectors to obtain higher profits. The process of selling carried out by farmers to collecting traders can be seen in the Table 2 .

Each type of coffee sold by farmers to collector traders will vary the results of product sales. Each stage of coffee processing determines the size of the coffee price. In this study, the average coffee production of farmers $700 \mathrm{~kg} / \mathrm{ha}$ of green bean (with a moisture content of 12\%). Farmers who usually sell coffee in the form of cherries will have different results to farmers who sell coffee in the form of green bean with the following calculations:

\section{Cherry}

- $700 \mathrm{~kg}$ of green bean $=4,200 \mathrm{~kg}$ of cherry coffee.

- 4,200 kg of cherries: $12 \mathrm{~kg}$ of cherries (size 1 kaleng of cherry coffee $)=350$ kaleng.

- 350 kaleng $\mathrm{x}$ IDR100,000=IDR35,000,000.

2. Green bean with moisture content (MC) $\geq 40 \%$

- 350 kaleng x $3.5 \mathrm{~kg}=1,225 \mathrm{~kg}$ of green bean $\mathrm{MC} \geq 40 \%$.

- $1,225 \mathrm{~kg}$ of grain $\mathrm{x}$ price of green bean $\mathrm{MC} \geq 40 \%$.

- 1,225 x IDR30,000 = IDR36,750,000.

Notes:

-1 kaleng of cherry coffee $=12 \mathrm{~kg}$ of cherry coffee.

- $6 \mathrm{~kg}$ of cherry coffee $=1 \mathrm{~kg}$ of green bean MC $11-12 \%$.

-1 kaleng of cherry coffee $=3.5 \mathrm{~kg}$ of green bean $\mathrm{MC} \geq$ $40 \%$.

Meanwhile in the foreign market (export), the Central Aceh Regency, which is the Gayo Arabica coffee producing region, is referred to as the producer country and foreign buyer is referred as consumer country. It can be seen that the production of Gayo Arabica coffee in 2016 was up to $\geq 25,000$ tons and as many as 20,000 tons $(80 \%)$ of the total coffee production was marketed in the world market. The majority of consumers of the Gayo Arabica coffee are advanced countries such as in the Americas and the European Union or referred to as consumer countries. Based on data from Badan 
Investasi dan Promosi Aceh, it is noted that the EU population is around 500 million, with the average amount coffee consumption of $5 \mathrm{~kg} /$ year.

Based on the market structure of the Gayo Arabica coffee on the international market, we can see that the price of coffee is always determined by the market. The determination of the prices set by the market has led the farmers to be in an unfavorable position. The farmers are in the first (lowest) layer of the coffee marketing system and the farmers are only as sellers and recipients of the offered prices from the marketing layers above them, because every layer of marketing is always looking for profits in purchasing coffee owned by farmers. The capital owned by the marketing layers is also very influential on the purchase of coffee at the farmer's level.

Collectors are the second layer in the Gayo Arabica coffee marketing system. Collectors are coffee buyers in each village and are located around the farmer's location. The process of purchasing coffee through farmers is done by the collectors who purchase the coffee fruit directly in the farm right after the harvest process is finished. For the purchase of grain coffee beans, the process is done through visiting the farmers who have grain coffee beans or vice versa. Hereafter, the collectors then sell the coffee beans to coffee businesses and exporters.

The certification cooperative is in the third layer in the market structure of Gayo Arabica coffee. The certification cooperatives is institution or business entities that market coffee based on the product certification. Farmers who are members of a certification cooperative will gain price transparency based on the buyer contracts on the New York market. The farmers can also find out to which country their coffee is exported. Certifications owned by coopera- tives are not only for product determination marketed in the New York market, but certification is an advantage for cooperatives in the coffee marketing process. Organic certification sets a premium price of USD $0.20 \%$ on each contract. While the Fairtrade certification sets a premium price of USD $0.44092 \%$ on each contract and the minimum price for purchasing Gayo Arabica coffee is the USD4,188 on the New York market. Coffee marketing is based on a certification system to continue to run, certification cooperatives must pay certification permits each year. The permit fee for organic certification is IDR100,000,000/year, while the permit fee for Fairtrade certification is IDR50,000,000/year. Calculation of contract value and price of premium product certification in the marketing system of the cooperative certification (one of cooperative in Aceh Tengah District) is presented as follows:

\section{a. Contract value}

- 19,000 kg x IDR64,000=IDR1,216,000,000.

- IDR1,216,000,000 x 60\%=IDR729,600,000 (the buyer gives $60 \%$ the contract value in the purchase process).

b. Price of organic certification premium (in 1 contract)

- (US\$ 0.20) x 18,000 kg

$-0.20 \%$ x IDR13,254 = IDR2,651

- IDR2,650.8 x 18,000 kg = IDR47,714,400

c. Fairtrade certification premium price (in 1 contract)

- (US\$0.44) x 18,000 kg

$-0.44 \%$ x IDR13,254 = IDR5,843.95

-IDR5,843.95 x 18,000 kg=IDR105,191,166

In 2016 'X' Cooperative had 10 contracts on the New York market with an average quantity of coffee of $18,000 \mathrm{~kg}$. If the value of each contract is IDR $1,216,000,000$, the total 
value of 10 contracts is IDR12,160,000,000. For the price of Organic certification premium on 10 contracts reached IDR477,144,000, while the price of Fairtrade's premium certification on 10 contracts reached IDR1,051,911,660 (1.05 billion more). The premium price obtained by ' $\mathrm{X}$ ' Cooperative from the sale of organic and fairtrade certification is IDR1,499,055,660 (1.4 billion more). Coffee farmers (members) of the $\mathrm{X}$ Cooperative currently number 2,000 farmers involved in the certification program. The involvement of farmers in the certification program gets 2 (two) benefits, namely the determination of the price of the coffee purchase contract and the benefits of the premium certification fund. That is farmers who are members of cooperatives with an average coffee production of $700 \mathrm{~kg}$ in grain coffee sales of IDR36,750,000 get additional profits from the total value of 10 organic and fairtrade certification contracts of IDR749,527. However, the amount of premium funds is not fully received by farmers, because the total profit from the total coffee sales premium funds must be spent on certification permit fees and cooperative operational costs. Along with the increasing popularity of Fairtrade and Gayo coffee in world trade, the higher the level of participation of Gayo coffee farmers in the Fairtrade certification network. Fairtrade certification provides several benefits to farmers, namely fair and transparent prices, more than premium funds (premium fees), and the position of farmers in the international market becomes stronger.

The fourth layer is the exporter. The coffee price is determined by the exporter based on a coffee purchase contract agreement with the buyer. In the marketing process, exporter must conduct partnerships with certification cooperatives and the Gayo Arabica coffee entrepreneurs/businesses in Central Aceh Regency. The partnership aims to determine the type of coffee, the quantity of coffee and the quality of coffee produced by each certification cooperative. The partnership will make it more convenient for the exporters to fulfill the demand of the buyer.

In the fifth layer, the Buyer is an International buyer who binds contract to purchase the Gayo Arabica coffee with a certification cooperative in the New York market. In the purchasing contract, there are regulations about the purchasing price of product certification. Without price regulation, rational buyers will try to find products with the lowest price in order to get maximum profits. In determining the price of Gayo Arabica coffee, the buyer will contact collectors (coffee marketing intermediary) who has the experience to get high-quality Gayo Arabica coffee to be marketed to the consumers. The relationship and approach between buyers and collectors has been going on for a long time by forming a trust system. The establishment of this system has the purpose to demonstrate professional performance.

\section{Social Relation Among Actors}

\section{Social relation among farmers}

The people of Gayo, who are generally coffee farmers, have cultural values or tribal characteristics in their community life. Some of the cultural values of Gayo farmers include working hard (mutentu), helping each other (alang tulung) and high self-esteem (bersememelen). These values become the idealism in the success of the coffee farms owned by the farmers. Each value shows the function and purpose of the farmers for activities regularly conducted in the cultivation of coffee plants and coffee production. The success of a farmer in the coffee cultivation management system and excellence in coffee production will become an example for other farmers. 
Generally, the Gayo Arabica coffee farmers interacting with other farmers regarding the development of each coffee plantation they manage, including the condition and location of the garden, the physical form of their coffee crops, types of coffee varieties, the processing of coffee, coffee production, and income. Different levels of education, income and experience will determine the coffee cultivation system, farm arrangement and coffee productivity level of each farmer. However, a strategic location of farm and accessibility by the farmers is the main determining factor in the development of coffee plantation for each farmer. If these factors are shared by two farmers, when there is a significant difference in the yields of these farmers in their coffee plants and coffee production, then the farmer who is not superior will feel ashamed to the superior farmer.

The social relation of fellow farmers based on mutual cooperation and friendliness can be seen in the process of the coffee farming, the process of harvesting the coffee cherry and the process of peeling the fruit of coffee cherry. Each farmer (farm owner) will involve several other farmers in the process of the coffee cultivation. The process of coffee cultivation includes the maintenance of the crops, fertilizer application and clearing of wild grass in the location of the coffee farms. Farmers who are involved in this process tend to have a special bond or kinship, and emotional relationships with farm owners. However, looking at the economic conditions of the farmers who were quite alarming, the farm owners will provide labor costs to the farmers who were involved in the activity process. Some technological equipment in the plantation subsector that is used at the Gayo Arabica coffee farmers in Central Aceh Regency includes grass-cutting machines, fertilizer spraying machines and fruit peeling machines for the coffee cherry. Farmers with a better economic status could easily have the technology of plantation sub-sector equipment. While farmers with lower economic level will find it difficult to have the technology of plantation sub-sector equipment and prefer to borrow from other farmers, especially those who have a bond of kinship.

In the process of harvesting the coffee cherry, farm owners will also use the help of other farmers to pick the coffee cherry. The coffee cherry picking activity is conducted based on the agreement of fellow farmers by assessing the maturity level of the coffee cherry picked of each farmer. The picking process of the coffee cherry is conducted alternately from one farm to another until finished. After the coffee cherry has been harvested, the farmer who is the owner of the farm will provide a salary to the farmers involved determined by the amount of coffee cherry they picked. Whereas in the process of peeling coffee cherry, the farmers who do not own a peeler machine, tend to bring their coffee to other farmers around the farmer's residence who owns one.

\section{Social relation between farmers and collectors}

During the coffee harvest season, the Collectors become the main target of the farmers in selling their coffee production. The existence of collectors around the location of the farm and the residence of farmers, as well as their ownership on facilities and equipment (transporting vehicles and coffee cherry peeler machine), cash payment and the availability of capital loans are the determining factors for the farmers to sell their coffee production to certain collectors of their choice. The close distance between the location of the farmer's residence and the collectors makes it easier for farmers to 
obtain coffee price information. Information on the coffee price will determine the income from the sale of coffee produced by the farmers. In general, the farmers will ask about the current price to several collectors located around the farmer's residence to look for differences in the price of coffee.

The limitation of the farmers for not owning vehicles and the peeling machine for coffee cherry is one of the causes for farmers to become always depend on collectors who have these facilities. Collectors generally purchase the coffee in the form of coffee cherry and grain using a pick-up truck by going around the coffee plantation area and the farmer's residence. Therefore will ease the farmers in the use of transportation facilities to transport their coffee production that has been picked in the farm or which has been processed into the grain. Seen from the average coffee production of farmers with the yield amount of $700 \mathrm{~kg} /$ hectare/year $( \pm 500 \mathrm{~kg}$ of coffee cherry/ week and $142 \mathrm{~kg}$ of grain/week) it must require 1 unit of pickup truck with an open tub to transport the coffee cherry and 1 unit of pedicab to transport the coffee grain, therefore it can be sold to the collectors.

The low level of the farmer's economy has led the farmers to rarely have transporting vehicle ownership that is needed during the coffee harvest season. Coffee farmers usually only own a motorbike which then is used to transport the farmer from their home to coffee plantations and for other purposes in the daily lives of the farmers. To transport the coffee product in the form of coffee cherry from the farm to the collectors, it certainly becomes a big risk to the farmer when it is packaged in a $50 \mathrm{~kg}$ plastic sack. The same procedure also found in grain coffee farmers. In addition to safety risks, the risk of damage to the motorbikes owned by farmers became another reason for the utilization of transporting vehicles owned by collectors.

Usually, the farmer who has emotional relation and kinship to the collectors has easier access for the processing of their coffee cherry. In this process, an agreement is usually carried out between the farmer and the collectors. After the coffee cherry has been processed into grain coffee beans, the farmer must sell it to the collectors with the previously determined price benchmark. If the farmer violates the agreement, the collectors will not be interested in buying the farmer's coffee. Thus, it will have an impact on the farmers in selling their coffee production in the next period, because the farmer have to find new collectors to sell their coffee for.

\section{Benefits for farmers as members of the certification cooperative}

Coffee certification is an activity to foster and educate the farmers about the proper and correct coffee cultivation process in accordance to the established standards, in order to improve their coffee quality and to encourage farmers to care about the environment and social conditions, therefore the farming is sustainable. The coffee certifications obtained by the certification cooperatives in Central Aceh Regency has only two types of certification, namely organic and fairtrade certification. In order to become a member of the certification cooperative, the Gayo Arabica coffee farmers in Central Aceh must follow a product certification program. Each product certification provides benefits for the farmers for their coffee plantation, products and the premium price provided by the product certification agencies to the farmers. 
In organic certification, there are several benefits which will be obtained by the farmers, including the cultivation system of their Arabica coffee plants will be carried out with organic system, social protection, and product protection. The Arabica coffee cultivation with the organic farming systems in principle is emphasizing the importance of preserving the environment by applying adequate cultivation practice, therefore, the crop production will be increased and sustainable. Additionally, organic certification also plays a role in marketing as the organic product is highly demanded by the consumers in developed countries. The organic certification is a process to obtain the recognition that the process of farming is organic or the processing of the organic product is conducted based on the predetermined standards and regulations. If it meets the organic standards and regulations, the producers will obtain an organic certificate and have the right to put organic labels on the products they produced and on the products when it is marketed.

Another benefit of this certification is that it will provide social protection which benefits the farmers and for child protection. The female farmers will also have the same opportunities as male farmers to obtain training, credit facilities, increase resources, nutrition, health, and protection from sexual harassment. Whereas for the protection of children, the farmers and the certification cooperatives must not hire children under 15 (fifteen) years old as workers, both as farm workers and workers in the certification cooperative. Because organic certification has determined that underage children must obtain equal education and recreation. The protection of products on organic certification is a guarantee for the products produced by the farmers. The guarantee of organic products makes it easy for the Gayo Arabica coffee farmers to market their coffee both in the domestic and international market.
The gayo Arabica coffee farmers in other regions in Central Aceh has also joined to become members of the fairtrade certification cooperative. The fairtrade is a social movement with a market-based approach which aims to reduce poverty at a global scale and to promote sustainable trade systems. The Central Aceh Gayo Arabica coffee farmers who join and have been registered by Fairtrade-certified cooperatives will gain benefit from the certification process. Due to the high cost of certification by the cooperatives as certification holders and ones who market the coffee in the fair trade. After gaining Fairtrade certification, cooperatives must conduct a number of procedures such as strengthening the organization, documenting activities and production, making reports and receiving visits from Fairtrade Labeling Organization (FLO) inspector, who will come to the site periodically both in terms of guidance and audit matters (Chairawaty, 2017). The FLO itself is a non-profit organization that is responsible for the directing and executing, setting standards and supporting producers and traders in trade activities within the fair trade.

The results of this paper indicate that social actors are participating in the coffee marketing process in Central Aceh Regency. In this paper, there are several actors involved, namely, farmers, collectors, certification cooperatives and exporters. Each actor has their duties and functions and unconsciously have built relationships that are interdependent and bound to one another. This fact also occurs in the process of marketing Arabica coffee in South Sulawesi in Rinding Allo District. Where market structures that do not compete perfectly lead to increased dependence of farmers on marketing domination by exporters and wholesalers (Sallatu, 2006). The form of dependence that occurred in this paper is not much different from what Sallatu mentioned. Coffee farmers depend on the 
presence of traders in providing the equipment needed to process coffee beans and as a means for coffee farmers to sell their coffee. Collecting traders can have several trading functions such as sales, purchasing, storage, transportation, selection, packaging, market information and financing functions (Siregar et al., 2015). While the determination of the price of coffee is not only determined by the international market but also by local prices. Therefore, farmers have two choices to market coffee, namely in domestic or export. Putri et al. (2013) stated that there were 4 coffee marketing channels in Aceh Tengah and Bener Meriah districts, namely the first channel, farmers-collectors-cooperatives-exporters (non-cooperatives). The second channel, farmer-collector-exporter (non-cooperative). The third channel, farmerscollectors-exporters (cooperatives) -exporters (non-cooperatives) and the fourth channel namely farmers-collectors-exporters (cooperatives). Through these studies and the results found by the authors indicate that the coffee marketing mechanism in Central Aceh Regency will involve at least 4 actors, namely farmers, collectors, cooperatives, and exporters.

\section{CONCLUSIONS}

The marketing mechanism of Gayo coffee in Central Aceh Regency involves several actors ranging from farmers, traders, and collectors which has caused the marketing system of Gayo Arabica coffee in Central Aceh District run in efficiently. Many processes must be passed cause farmers always receive the lowest prices that have an impact on farmers income from the production of coffee plants. The existence of cooperative certification, ownership of product certification and Warehouse Receipt System which is the governments concern for farmers, has not been able to increase farmers income from coffee sales. Product certification only provides space in the coffee marketing process both in short and long term. The benefits of full product certification are only felt by exporters and collectors to seek profits with the capital they have in purchasing coffee. While farmers are only involved as producers of products from certification programs and offer price recipients (price takers). The relationship among actors is an associative relationship. The relationship between cultural farmers where the community still applies the value of cooperation between them is good, especially in coffee harvesting and maintenance of coffee plants. The relationship between farmers and collectors is also a collaboration where the collectors help farmers in providing the equipment needed by farmers in this coffee plantation activity. However, as this activity progresses, the relationships between them become dependent relationships, where farmers depend on the price of coffee determined by international and local markets.

\section{REFERENCES}

Chairawaty, F. (2017). Dampak pelaksanaan perlindungan lingkungan melalui sertifikasi Fair Trade (studi kasus: petani kopi anggota Koperasi Permata Gayo, Kabupaten Bener Meriah, Nanggroe Aceh Darussalam). Jurnal Ilmu Lingkungan, 10, 76-84.

Martauli, E.D. (2018). Analysis of coffee production in Indonesia. Journal of Agribusiness Science, 1, 112-120.

Nurlina \& E. Putra (2016). An analysis of factors affect the export of Gayo coffee in Bener Meriah Regency, Aceh, Indonesia. Academic Journal of Economic Studies, 2, 102-113.

Ditjenbun (2016). Statistik Perkebunan Indonesia (The Crop Estate Statistics of Indonesia). Direktorat Jenderal PerkebunanKementerian Pertanian. Jakarta. 
Purnomo, M. (2018). Contesting Indonesia's single origin coffee market: A dynamic capabilities perspective. Asian Social Science, 14, 91-101.

Putri, M.A.; A. Fariyanti \& N. Kusnadi (2013). Struktur dan integrasi pasar kopi Arabika Gayo di Kabupaten Aceh Tengah dan Bener Meriah. Buletin RISTRI, 4, 47-54.

Sari, D.R. \& E. Tety (2017). Export competitiveness analysis of coffee Indonesia in the world market. Jurnal Ilmiah Ekonomi dan Bisnis Maret, 14, 105-114.

Sallatu, I.A. (2006). Analisa Pangsa Pasar dan Tataniaga Kopi Arabika di Kabupaten
Tana Toraja dan Enrekang, Sulawesi Selatan. Tesis, Institut Pertanian Bogor. Bogor, Indonesia.

Sarirahayu, K. \& A. Aprianingsih (2018). Strategy to improving smallholder coffee farmers productivity. The Asian Journal of Technology Management (AJTM). 11, 1-9.

Siregar, M.; Salminah \& Iskandaini (2015). Analisis tataniaga rambutan di kota binjai (Studi kasus: Kelurahan Pahlawan, Kabupaten Langkat). Journal of Agriculture and Agribusiness Socioeconomics. 2, 1-11.

$* * 0 * *$ 